\title{
HRM Practices of Women's Microenterprises in A Developed Economy Context: A Few Case Studies
}

\author{
Kumudinei Dissanayake \\ University of Colombo, Sri Lanka
}

\begin{abstract}
Human resource management (HRM) is an important function irrespective of the size of the enterprise. Microenterprises (MEs) lack formal HRM systems, and thus reluctantly adopt such practices even in developed economies. Acquiring suitable human resources for women's microenterprises has been problematic due to several reasons, such as high labor cost which is unbearable for MEs, MEs are not attractive for sustainable careers, women's businesses are less attractive, and microenterprises are not that promising for young workers. Thus, it is interesting and exciting to learn how women micro-entrepreneurs manage human resources for the survival of their enterprises. Present study explores the best practices adopted by microenterprises led by women in a developed economy context. This study deploys a qualitative enquiry which consisted of semi-structured, in-depth, exploratory interviews with 15 women microentrepreneurs based in Tokyo, Japan in this exploration. The results reveal the vital issues faced by women micro-entrepreneurs and several interesting HRM strategies adopted by them for survival and growth of the businesses.
\end{abstract}

Keywords: Best practices; Enterprise survival; HRM strategies; Qualitative enquiry; Vital issues 